\title{
Paradigm Shift in the Schools of European Structuralism: From Pre-Structuralism to Post-Structuralism
}

\author{
Mohammed A. Abuzaifah ${ }^{1}$ \\ ${ }^{1}$ College of Languages and Translation, King Khalid University, Saudi Arabia \\ Correspondence: Mohammed A. Abuzaifah, PhD Candidate, College of Languages and Translation, King Khalid \\ University, Saudi Arabia. E-mail: m.alzaifah@hotmail.com
}

Received: April 12, 2021

Accepted: May 20, $2021 \quad$ Online Published: June 7, 2021

doi:10.5539/ijel.v11n4p26

URL: https://doi.org/10.5539/ijel.v11n4p26

\begin{abstract}
The present article aims to review the paradigm shift, a concept proposed by Thomas Kuhn (1962), and how its manifestation in the developments of language studies contributed to the advent of different structural schools of European linguistics. To further explore the topic, this article begins by identifying the actual meaning of Kuhn's paradigm shift and how it influenced other disciplines of science. Second, the history of structuralism is discussed and reviewed from two different perspectives, pre stage and the post stage of structuralism. The revolutions throughout the history of structuralism, primarily in the European context, led to paradigmatic shifts and the emergence of several influential and prominent structural schools, namely European structuralism, the Prague Linguistic Circle, and the London school of linguistics.
\end{abstract}

Keywords: structuralism, European structuralism, Prague linguistic circle, London school of linguistics, linguistics

\section{Introduction}

Structuralism, a prominent school of linguistics, has undergone several changes to its concepts, principles, and assumptions since it was first founded in Europe by the Swiss linguist and the father of modern linguistics Ferdinand de Saussure, in 1920. These changes resulted in several paradigms being enunciated by different linguists and different schools of linguistics in different sociocultural contexts. In this article, I will discuss, review, and highlight the development of these paradigms, mainly within the influential European schools of linguistics, starting with European structuralism, poststructuralism, and the Prague linguistic circle. I will conclude with the London school of linguistics. I have purposefully narrowed the focus of this article and will study and discuss the European schools of linguistics, mainly structural schools, to analyze the paradigm shift occurring within one unified context, the European context of structural linguistics. American structuralism and other schools across the world have not been considered for this reason. Finally, it is worth noting that other influential European schools of structuralism, for example, the Moscow Linguistic Circle, the Copenhagen School, and the Geneva School of Linguistics, have not been discussed due to the article's limited scope.

It is important to begin by highlighting the main principles of the "paradigm shift" concept and how they are relevant to the developmental changes that occurred in European structuralism. The paradigm shift is a scientific concept introduced by the American physicist and philosopher Thomas Kuhn in his influential book The Structure of Scientific Revolutions (1962). Kuhn contrasts paradigm shifts that represent scientific revolution with normal scientific activity, which is described as scientific work done within a fundamental framework or paradigm. Kuhn (1962) argues that "paradigm shifts arise when the dominant paradigm under which normal science operates is rendered incompatible with new phenomena, facilitating the adoption of a new theory or paradigm" (p. 54). Kuhn distinguishes four phases of the paradigm shift: the preparadigmatic phase, the normal science phase, the crisis phase, and the scientific revolution phase. Scientists consider the normal phase as when the main scientific activity of solving scientific problems occurs within a paradigm itself. If a concept within a scientific paradigm fails to meet that standards of the scientific discipline, lacks a fundamental aspect, or violates a scientific rule, Kuhn's (1962) crisis phase begins here. At this phase, examining the scientific concept is being considered and must be initiated. From then on, investigation, research, and other scientific experiments embark on solving problems identified in the paradigm, which results in a newer version of the paradigm. This process of testing a paradigm and renewing it can occur several times and on several levels of the paradigm. This shifts a 
scientific paradigm from its original and basic version to a revised and updated version. This cycle can be repeated a number of times. This process of investigation and reinvestigation is Kuhn's (1962) paradigm shift.

The concept of paradigm shift has made its presence clear in different areas of science. In this article, our primary concern is to observe how the changes and developments that occurred in the school of structuralism are best understood as a paradigm shift.

\section{Structuralism}

The Oxford Dictionary defines structuralism in literature, language, and social science as "a theory that considers any text as a structure whose various parts only have meaning when they are considered about each other" (2021). Etymologically, the term structuralism comes from the Latin term struere, derived from structura (Dosse, 1998). The term structure initially had an architectural meaning and referred to the way in which a building is constructed (Trevoux dictionary, 1771, cited in Dosse, 1998). Nonetheless, the term structure had a different meaning in the seventeenth and eighteenth centuries, broadened by analogy to include living creatures (Dosse, 1998). However, the adaption of the term was not applied to language or language studies at first: at the early stages of development and implementation, the term structure was used to refer to the human body (cf. Fontenelle), though Vaugelas and Bernot had a distinct linguistic view of the term and used it to refer to language. In a broader sense, the word structure was used to describe parts of a concrete object, i.e., tangible, being structured into a whole (Dosse, 1998). Hence, this simplified definition of the term makes it applicable to different scientific disciplines, such as psychology, geology, mathematics, and linguistics.

The term structuralism was not found in dictionaries and books before 1900. Between 1900 and 1926, the concept of structuralism made its first debut in the work of Andre Lalande, Vocabulaire. The term structuralism was first used in psychology by Wilhelm Wundt and further developed by his student Edward B. Titchener through the early 1920s (Lopez-Garrido, 2021). Dosse (1991/1997) indicates that "the true origins of the term structuralism, in its modern sense, and on the scale of all human sciences, comes from the developments in the field of linguistics" (p. 22). Saussure, in his book Course in General Linguistics, published in 1916, used the term structure only three times. In the 1920s, Jacobson and Trubetzkoy, from the Prague school of linguistics, generalized the use of both terms, structure and structuralism.

The term structuralism thus has variable meanings that depend on the scientific field it concerns. However, in linguistics, structuralism is "a general theory of culture and methodology that implies that elements of human culture must be understood by way of their relationship to a broader system" (Calhoun, 2002)

\subsection{Prestructuralism}

Structuralism was not known as an intellectual movement before 1920. Many believed that structuralism in the early nineteenth century was viewed as "the apparent heir to existentialism" (Nasrullah, 2016 [online source]). Janko (1971) defined existentialism as "a form of philosophical inquiry that explores the problem of human existence and centers on the lived experience of the thinking, feeling, acting individual" (p. 43). Structuralism and existentialism appeared related in the way they both attempt to find the underlying meaning of a text. I believe the similarity between the two schools of thought, in this sense, might have been responsible for the skeptical behavior of the advocates of both schools of the nineteenth century.

\subsection{European Structuralism}

Structuralism was developed in France, Eastern Europe, and the Russian Empire in the early twentieth century with the writings of Ferdinand de Saussure and the subsequent schools of linguistics; Prague, Moscow, and Copenhagen schools (Gilles, 2002). It is assumed that structuralism began in the early 1900s with the writings of Ferdinand de Saussure, who is considered the father of modern linguistics. In 1916, Saussure delivered several lectures in linguistics. Later, after his death, his students compiled his lectures and published them in an influential book titled Course in General Linguistics. This book provided the foundation for modern linguistics, as well as semiotics (Pieter, 1998, cited in "Structural linguistics, 1951"). Structural linguistics, according to Pieter (1998), is "often thought of as giving rise to independent European and American traditions, due to ambiguity in the term" (cited in "Structural linguistics, 1951"). Although many linguists believe that the writings of Saussure mark the beginning of European structuralism and modern linguistics in general, the American school of linguistics, based on Wilhelm Wundt's structural psychology, rejected this claim (Pieter, 1998, cited in "Structural linguistics, 1951"). Stranzy (2005) asserts,

"It is important to stress that structuralism did not initially emerge as a school of thought or a philosophical tendency. Yet, toward the end of the nineteenth century and in the early decades of the twentieth century, structuralism had established itself as a major force to reckon with, reaching its pinnacle of glory by the 1930s" 
(p. 1041).

It seems that Saussure, the founder of European structuralism, was not satisfied with the traditional grammar system of the scholars of Greek and Latin, as they followed a prescriptive approach in studying grammatical structures and concepts of language. It can be noticed that the aim of Saussure's approach is to tell what language is and what we mean by the term 'language' itself. He also criticized comparative grammar and said that this comparison only answers where a language comes from. This background tells us about linguistics in general and how it emerged.

One of the main characteristics of European structuralism, founded by Saussure, is that it introduced a new approach to the study of language, the descriptive approach, which is different from the prescriptive approach proposed originally by traditional grammar. It also managed to introduce four other concepts, Saussure's dichotomies (described below), which helped linguists study the language and were also credited with making linguistics stand as an independent field of science.

Saussure had a great impact on European structuralism in particular and on linguistics in general, and his influence is of great significance. Apart from Saussure's contributions to linguistics, which will be summarized and highlighted in the next section, Ruqaiya Hasan argues that "the impact of Saussure's theory of the linguistic sign has been such that modern linguists and their theories have since been positioned by reference to him: they are known as pre-Saussurean, Saussurean, anti-Saussurean, post-Saussurean, or non-Saussure" (Yang \& Webster, 2013, p. [needed]).

European structuralism is viewed as by far the most influential school of linguistics in Europe, and it has a unique set of principles. It is worth mentioning again that structuralism is a school of thought that refers to a set of principles of language study. Furthermore, linguists realize that the principles of European structuralism are similar to the principles of linguistics as a scientific discipline (cf. Van de Walle et al., 2006). The first principle is that European structuralism is a descriptive study of language. Secondly, it appears that each language has its own structure; this principle is similar to the principles of linguistics as a scientific discipline. Thirdly, it can be noted that language is fundamentally a system. Before structuralism, language was studied in an atomistic way: each unit was studied individually, by itself. In the structuralist system, language is studied from a relational standpoint. That is, it is a relational system. This system incorporates different relationships that exist between linguistic units. Fourthly, another principle indicates that each unit in the structure carries a certain value. The value of each unit is determined by other units in the structure, and each unit contributes to the overall meaning of the whole structure. Finally, language can also be defined as a structured system of relational oppositions. To understand this, we should study the difference between the units inside this structure itself. This is what we call the relation of positions.

Another influential contribution to European structuralism can be found in Ferdinand de Saussure's book Course in General Linguistics (1916). Among several illuminating and significant comparisons included in the book, Saussure introduces the notion of dichotomies. In brief, this set of dichotomies includes langue versus parole, synchrony versus diachrony, paradigmatic versus syntagmatic, and signifier versus signified (Laurie, 2007).

\subsection{Poststructuralism}

According to Kuhn (1962), paradigm shift cannot be explained in the absence of scholarly criticism, and thus, the historical development of paradigmatic shifts will help to unravel the mystery of how structuralism underwent various phases. It can be noted that European structuralism was prominent and dominant for about three decades, from 1950 to 1980. In that period, linguists admired Saussure's concepts and theories. As previously mentioned, structuralism in Europe started in the early twentieth century, mainly in France and the Russian Empire (Gilles, 2002). It appears that European structuralism was dominant until the late 1950s and early 1960s until this intellectual movement was contested and questioned by thinkers like Noam Chomsky, Michel Foucault, Jacques Derrida, and Marxist philosopher Louis Althusser (Simon, 2008). This criticism, in addition to the challenges that European structuralism had encountered (highlighted in the coming section), sparked the beginning of a new paradigm of the structuralist theory founded by Saussure.

Gilles (2002) argues that "by the late 1960s, many of structuralism's basic tenets came under attack from a new wave of predominantly French intellectuals/philosophers such as historian Michel Foucault, Jacques Derrida, Marxist philosopher Louis Althusser, and literary critic Roland Barthes" (Gilles, 2002). Although some concepts of these philosophers and intellectuals were essentially pertinent to structuralism, these thinkers have generally been described as poststructuralists. Also, in the 1970s, "structuralism was criticized for its rigidity and ahistoricism" (Mason \& Clarke, 2010). Nonetheless, it seems that many advocates of structuralism, such as Lacan (1956), “continue to influence numerous fundamental assumptions of some of structuralism's 
post-structuralist critics and are a continuation of structuralism" (John, 1979).

To best describe the paradigm shift that structuralism went through, I will have to refer to Alan's (2013) commentary. In the 1970s, there was a shift of focus in the Annales School that, according to Alan (2013), "would play a part in the larger shift from structuralist paradigms to the emergence of post-structuralist models" (p. 5). Furthermore, Alan (2013) states that the "efforts of earlier structuralists had evidenced concern for scientific objectivity ... [for] Saussure's linguistic endeavors (p. 5)." That said, it is evident that the new trend required a greater position for subjective elements to encourage the perspective of normal people by focusing on mentalities, which can be viewed, in essence, as the inner attitudes of people within their historical perspectives. Alan (2013) adds, "This facilitated the move to post-structuralism, which exploits the view of knowledge as limited by perspectives" (p. 5).

\subsection{Prague School (or Prague Linguistic Circle)}

Structuralism experienced another paradigm shift, pioneered by the Russian linguist Roman Jakobson (1896-1982). Jakobson was Russian, but when the transition and the modifications were occurring to structuralist theory, he was residing in Czechoslovakia. In 1926, Prague linguists led by Jakobson built on Saussure's ideas and concepts in the field of structural linguistics and furthered this argument. In this section, I will outline the similarities between the two schools and how the new paradigm shift was introduced at this stage, and I will highlight how these two schools differed in some aspects of the theory.

The Prague school of linguistics has been an influential school of thought that has played a crucial role in the history of modern linguistics. Its contributions to the field of linguistics are remarkable. In the context of language and linguistics studies, there has always been a connection between the Prague school of linguistics and Saussure's structuralism that presumably came about as a result of the common points they share. The Prague school also played a significant role in Indo-European linguistics, beginning when the first group of linguists gathered in a recorded meeting on March 13, 1925, in a café in Prague. Salah (2009) states that "the names of Mathesius, Trubetzkoy, Jakobson, Trnka, Skalichka, etc., have become part of the reading canon of Indo-European linguistics (p. 3)." It might be worth stating that after World War II, the Prague circle of linguists parted ways, but the school itself continued as a key force in linguistic functionalism. The paradigm shift that the Prague school of linguistics adopted can be formulated on new grounds, as linguists of the Prague school "stress the function of elements within language, the contrast of language elements to one another, and the total pattern or system formed by these contrasts, and they have distinguished themselves in the study of sound systems" ("Prague School," 2015).

Now, we will discuss and review the London school of linguistics, which, like the Prague school, emerged in the twentieth century.

\subsection{London School of Linguistics}

The label given to the London school, in its strictest sense, refers to a group of linguists led by John R. Firth (1890-1960). His students and advocates were the first students at the School of African and Oriental Studies. One of his most influential students, who took up many of his ideas and concepts, is M. A. K. Halliday, who later founded the school of systemic functional linguistics (SFL) in Sydney, Australia. The London school had the same common principles as the British structural linguistics while counting on the research of Saussure and the Prague school. The London school's thinking developed autonomously. The works of the scholars Danial Jones (1881-1967) and Alan H. Gardiner (1879-1963) represented this autonomy.

The paradigm shift within the theory of structuralism took place in the London school in a different way to the Prague School of Linguistics. The London school concentrated on the semantic aspect of language, though it followed Saussure's path of synchrony. However, it seems to have rejected the concept of the collective and social experience of speech, focusing instead on studying the speech of the individual person.

Another aspect of the London school was the study of phonemes. Jones, for example, was "a leading phonetician, who dealt with the notion of the phoneme in the second decade of the twentieth century, earlier than Trubetzkoy and other Prague linguists" (Allan, 2013, p. 483). Allan (2013) indicates that "Jones did not define the phoneme in terms of 'relevance,' but as 'a family of uttered sounds [...] in a particular language which counts for practical purposes as if they were one and the same" (p. 3). On the other hand, Gardiner (1951), an outstanding Egyptologist, devoted a book to "the theory of speech of language," which "respectively translated de Saussure's notion of parole and langue" (Allan, 2013, p. 471). The difference between Gardiner's notion of parole and langue and Saussure's language function is, according to Allan (2013), that Saussure views parole as something accessory or more or less accidental, while Gardiner views the notion of speech as central. Gardiner, however, 
defines it as "a set of reactions to external stimuli" (Allan, 2013, p. 483). It is obvious that both scholars have completely different views on parole.

\section{Conclusion}

The European structural schools of linguistics, namely European structuralism, poststructuralism, the Prague school of linguistics (Prague linguistic circle), and the London school of linguistics, have different paradigms of structuralism. They developed several approaches to formulate new schools of thought, reliant on the school that adopted Saussure's teachings, and that which had been influenced by the notions he introduced to the field of language study. It is clear now that the revolutions throughout the history of structuralism, chiefly in the European context, proved to have led to paradigmatic shifts, which therefore resulted in the emergence of some influential and prominent structural schools, namely European structuralism, the Prague linguistic circle, and the London school of linguistics.

Although European structuralism was under attack by linguists of the twentieth century (e.g., Noam Chomsky and other linguists) for being rigid and ahistorical (John, 1979), the school of Saussure did not renounce its existence. Instead, Saussure's school persisted and proved to be compliant and adaptable by modern schools of linguistics, and it thus continues to give rise to several new scientific paradigms.

\section{References}

Bauer, L. (2007). The linguistics student's handbook. Edinburgh: Edinburgh University Press.

Blackburn, S. (Ed.). (2008). Structuralism. In Oxford dictionary of philosophy (2nd rev. ed., p. 353). Oxford: Oxford University Press.

Calhoun, C. (Ed.). (2002). Structuralism. In Dictionary of the social sciences. Oxford: Oxford University Press.

Corlew, A. (Alan). (2013). Poststructuralism as historiographical paradigm. SSRN Electronic Journal.

Deleuze, G. (Gilles). (2002). How do we recognise structuralism? In Desert islands and other texts 1953-1974 (D. Lapoujade, trans., M. Taormina, ed.). Semiotext(e) foreign agents ser. (p. 170). Los Angeles: Semiotext(e), 2004. 170-192.

Dosse, F. (1998). History of structuralism: The rising sign, 1945-1966 present (Vol. 1, E. Glassman, trans.). University of Minnesota Press. (Original work published 1991)

Fang, Y., \& Webster, J. (2013). Developing systemic functional linguistics: Theory and application. London: Equinox.

Harris, Z. S. (1951). Methods in structural linguistics (also known as Structural Linguistics). University of Chicago Press.

Kuhn, T. S. (1962). The structure of scientific revolutions (1st ed.). Chicago: University of Chicago Press.

Lavrin, J. (1971). Nietzsche: A biographical introduction. London, Studio Vista: Scribner.

Lopez-Garrido, G. (2021). Structuralism and Titchener. Simply Psychology. Retrieved from https://www.simplypsychology.org/structuralism.html

Mambrol, N. (2016). Structuralism. In Literary theory and criticism notes. Online source. Retrieved from https://literariness.org

Mambrol, N. (2016, March 21). Jacques Derrida's structure, sign and play. Literary Theory and Criticism.

Mason, M., \& Clarke, M. (2010). Post-structuralism and Education. In International encyclopedia of education (3rd ed.). Oxford: Elsevier. https://doi.org/10.1016/B978-0-08-044894-7.01730-9

Paradigm shift. (2020, December 7). In Wikipedia. Retrieved from https://en.wikipedia.org/w/index.php?title=Paradigm_shift\&oldid=992805132

Prague school. (2015, November 08). In Encyclopedia Britannica. Retrieved from https://www.britannica.com/topic/Prague-school

Salih, S. (2009). Structuralism or functionalism? The linguistic theory of Prague school. ResearchGate. Retrieved from https://www.researchgate.net/publication/342591293_Structuralism_or_Functionalism_The_Linguistic_The ory_of_Prague_School

Seuren, P. A. M. (1998). Western linguistics: An historical introduction. London: Routledge. Wiley-Blackwell. https://doi.org/10.1002/9781444307467 
Strazny, P. (2005). Encyclopedia of linguistics. New York: Fitzroy Dearborn

Structuralism. (2020, Oct.) In Wikipedia. Retrieved from https://www.google.com/search?q=structuralism+wikipedia\&rlz=1C1CHBD_enSA848SA848\&oq=structur alism+wi\&aqs $=$ chrome. $2.69 \mathrm{i} 57 \mathrm{j} 015 \mathrm{j} 69 \mathrm{i} 6012.7604 \mathrm{j} 0 \mathrm{j} 4 \&$ sourceid=chrome\&ie=UTF-8

Structuralism. (2021, 6 April). In Oxford advanced American dictionary. Retrieved from https://www.oxfordlearnersdictionaries.com/definition/american_english/structuralism

Sturrock, J. (1979). Introduction. In Structuralism and since: From Lévi Strauss to Derrida. Oxford: Oxford University Press.

Van de Walle, J., Willems, D., \& Klaas, W. (2006). Handbook of pragmatics. Amsterdam: John Benjamins.

\section{Copyrights}

Copyright for this article is retained by the author, with first publication rights granted to the journal.

This is an open-access article distributed under the terms and conditions of the Creative Commons Attribution license (http://creativecommons.org/licenses/by/4.0/). 